\title{
Targeted integration of genes into the Clostridium acetobutylicum chromosome
}

\author{
Shane R. Wilkinson and Michael Young \\ Author for correspondence: Michael Young. Tel: +44970 622348. Fax: +44970622350 \\ e-mail: miy@uk.ac.aber
}

Institute of Biological Sciences, University of Wales, Aberystwyth, Dyfed SY23 3DA, UK

\begin{abstract}
A number of non-replicative, integrational plasmids have been introduced into the chromosome of the NCIMB 8052 strain of Clostridium acetobutylicum. Integration occurred via homologous recombination, apparently by a Campbell-like mechanism. For plasmids containing internal fragments of gut $D$ or spo0A, insertion was mutagenic leading, respectively, to an inability to use sorbitol as sole source of carbon for energy and growth or an inability to form endospores. One insertion was used to determine the map location of a randomly cloned DNA fragment and another underwent amplification in the bacterial chromosome. These results suggest that integrational plasmids will be very useful tools for genetic analysis in Clostridium acetobutylicum. To our knowledge, this is the first demonstration of gene transfer involving homologous recombination with the chromosome of any species of Clostridium.
\end{abstract}

Keywords: insertional mutagenesis, gene amplification, homologous recombination, integrational plasmid, Clostridium acetobutylicum

\section{INTRODUCTION}

Substantial advances have recently been made in the genetic analysis of mesophilic, saccharolytic clostridia (reviewed by Young et al., 1989; Young \& Cole, 1993). Clostridium acetobutylicum, well known for the acetone/ butanol/ethanol fermentation that it undertakes (Jones \& Woods, 1986), has become the favoured species for experimental genetics. A wide variety of plasmid vectors are now available (Minton et al., 1993) and genes have been transferred to this organism by protoplast transformation (Azeddoug et al., 1992), electro-transformation (Oultram et al., 1988; Mermelstein et al., 1992) and conjugation (Williams et al., 1990). Streptococcal conjugative transposons have been used for isolating mutant strains (Woolley et al., 1989; Bertram et al., 1990) and they are also being employed for constructing a physical map of the bacterial chromosome (Wilkinson \& Young, 1993). Gene transfer involving homologous recombination with the bacterial chromosome has not yet been documented. This remains a significant lacuna in the genetic analysis of all clostridia, including $C$. acetobutylicum.

Integrational plasmids may be employed to detect homologous recombination involving bacterial chromosomes. They contain a DNA segment from a host in which they cannot replicate, together with a genetic marker for which selection can be made. After transfer they become established by inserting into the homologous region of the host replicon from which the DNA segment was derived. Integration is generally assumed to occur by a Campbell-like mechanism (Campbell, 1962). After insertion, plasmid sequences at the target site are flanked by two directly repeated copies of the DNA segment directing integration. These duplicated sequences are potential substrates for homologous recombination, resulting in loss of the integrated plasmid. Therefore, insertion mutations created by plasmid integration are not completely stable. Integrational plasmids have proved to be extremely powerful tools in the genetic analysis of Gram-positive bacteria (reviewed by Dowds et al., 1988; Young \& Hranueli, 1988; Perego, 1993). For example, insertion can be mutagenic if the host sequences providing homology for integration lie entirely within a gene or transcription unit (Piggot et al., 1984). Another application is the controlled and relatively stable amplification of genes encoded by integrational plasmids (Young, 1984; Jannière et al., 1985; Piggot \& Curtis, 1987; Young \& Ehrlich, 1989). This communication documents the establishment of integrational plasmids by homologous recombination in the chromosome of the NCIMB 8052 strain of $C$. acetobutylicum.

\section{METHODS}

Bacterial strains and plasmids. These are listed in Table 1. 
Table 1. Bacterial strains and plasmids

\begin{tabular}{|c|c|c|}
\hline Strain & Genotype & Source/reference \\
\hline \multicolumn{3}{|l|}{ E. coli } \\
\hline $\mathrm{DH} 5 \alpha$ & 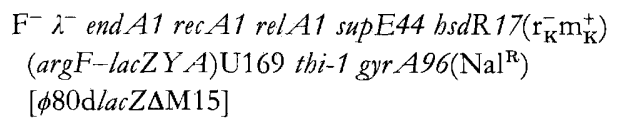 & Hanahan (1983) \\
\hline HB101 & $\begin{array}{l}\mathrm{F}^{-} \lambda^{-} \text {bsdS } 20\left(\mathrm{r}_{\mathrm{B}}^{-} \mathrm{m}_{\mathrm{B}}^{-}\right) \operatorname{supE} 44 \text { aro-14 galK2 lac } Y 1 \\
\left.\text { proA2 rpsL20( } \mathrm{Sm}^{\mathrm{R}}\right) \times y l-5 \text { mtl-1 rec } A 13\end{array}$ & Boyer \& Roulland-Dussoix (1969) \\
\hline CA474 & $\begin{array}{l}\mathrm{F}^{-} \lambda c 1857 \text { bsdS } 20\left(\mathrm{r}_{\mathrm{B}}^{-} \mathrm{m}_{\mathrm{B}}^{-}\right) \sup E 44 \text { aro-14 galK2 } \\
\text { lacY1 pro A2 rpsL20( }\left(\mathrm{Sm}^{\mathrm{R}}\right) \times y l-5 \mathrm{mtl}-1 \mathrm{rec} A 13\end{array}$ & $\lambda c 1857$ lysogen of HB101 containing R702 \\
\hline \multicolumn{3}{|l|}{ C. acetobutylicum } \\
\hline NCIMB 8052 & Prototrophic & Laboratory stock \\
\hline AA210 & erm & Insertion of pSRW 35 in NCIMB 8052 \\
\hline AA219 & gutD::erm & Insertion of $\mathrm{pJ} 1$ in NCIMB 8052 \\
\hline AA225 & erm & Insertion of pSRW 38 in NCIMB 8052 \\
\hline AA243 & spo0A::erm & Insertion of pSRW44 in NCIMB 8052 \\
\hline Plasmid & Relevant characteristics*/construction & Source/reference \\
\hline $\mathrm{R} 702$ & $\mathrm{Km}^{\mathrm{R}} ; \mathrm{Tra}^{+} \mathrm{Mob}^{+}$ & Hedges \& Jacob (1974) \\
\hline pAT153 & $\mathrm{Ap}^{\mathrm{R}}$ & Twigg \& Sherratt (1980) \\
\hline pUC19 & $A p^{R}$ & Norrander et al. (1983) \\
\hline pMTL30 & $\mathrm{Ap}^{\mathrm{R}} \mathrm{Em}^{\mathrm{R}} ; \mathrm{Tra}^{-} \mathrm{Mob}^{+}$ & Williams et al. (1990) \\
\hline pCTC1 & $\mathrm{Ap}^{\mathrm{R}} \mathrm{Em}^{\mathrm{R}} ; \mathrm{Tra}^{-} \mathrm{Mob}^{+}$ & Williams et al. (1990) \\
\hline pBTM100† & $\begin{array}{l}\mathrm{Ap}^{\mathrm{R}} \text {; pAT153 Bam HI containing } 8.1 \mathrm{kbp} \text { partial } \\
\text { Sau3A fragment }\end{array}$ & $\begin{array}{l}\text { N. P. Minton and J. D. Oultram, } \\
\text { PHLS, Porton Down, UK }\end{array}$ \\
\hline pCACB4† & $\begin{array}{l}\mathrm{Ap}^{\mathrm{R}} ; \mathrm{pUC19} \text { EcoRI/BamHI containing PCR- } \\
\text { amplified } 540 \mathrm{bp} \text { internal fragment of } s p o 0 \mathrm{~A}\end{array}$ & $\begin{array}{l}\text { D. Brown and P. Youngman, Univ. } \\
\text { Georgia, Athens, USA }\end{array}$ \\
\hline pJ1† & 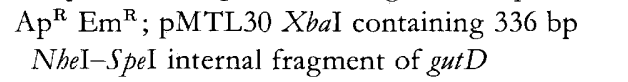 & $\begin{array}{l}\text { M. Mauchline and N. P. Minton, } \\
\text { PHLS, Porton Down, UK }\end{array}$ \\
\hline pSRW35† & $\begin{array}{l}\mathrm{Ap}^{\mathrm{R}} \mathrm{Em}^{\mathrm{R}} \text {; pMTL30 HindIII containing } 0.8 \mathrm{kbp} \\
\text { HindIII fragment }\end{array}$ & This study \\
\hline pSRW38† & $\begin{array}{l}\mathrm{Ap}^{\mathrm{R}} \mathrm{Em}^{\mathrm{R}} \text {; pMTL30 EcoRI containing } 3.8 \mathrm{kbp} \\
\text { EcoRI fragment from the insert in pBTM100 }\end{array}$ & This study \\
\hline pSRW44† & $\begin{array}{l}\mathrm{Ap}^{\mathrm{R}} \mathrm{Em}^{\mathrm{R}} ; \mathrm{pMTL} 30 \text { EcoRI/Bam } \mathrm{HI} \text { containing } \\
540 \text { bp internal fragment of } s p 00 A \text { from } \\
\text { pCACB4 }\end{array}$ & This study \\
\hline
\end{tabular}

${ }^{*} \mathrm{Km}^{\mathrm{R}}, \mathrm{Ap}^{\mathrm{R}}, \mathrm{Em}^{\mathrm{R}}$, resistance to kanamycin, ampicillin and erythromycin, tespectively; Tra, Mob, ability of plasmids to transfer by conjugation and to be mobilized by conjugation, respectively.

† Plasmids containing fragments of the C. acetobutylicum NCIMB 8052 chromosome.

Culture media and growth conditions. Clostridium acetobutylicum NCIMB 8052 was grown anaerobically at $37^{\circ} \mathrm{C}$ in clostridial basal medium (CBM; O'Brien \& Morris, 1971) solidified, as appropriate, with $1.5 \%(\mathrm{w} / \mathrm{v})$ agar. Derivatives harbouring integrational plasmids were selected on CBM supplemented with $10 \mu \mathrm{g}$ erythromycin $\mathrm{ml}^{-1}$. All Escherichia coli strains were grown aerobically on Luria-Bertani medium (LB; Maniatis et al., 1982) at $37^{\circ} \mathrm{C}$ (for $\mathrm{DH} 5 \alpha$ derivatives) and $30^{\circ} \mathrm{C}$ (for CA474 derivatives).

DNA isolation. Plasmids were isolated from E. coli using the method of Del Sal et al. (1988).

Chromosomal DNA was isolated from C. acetobutylicum using a method based on that of Stojanović et al. (1992). Bacteria from a $5 \mathrm{ml}$ overnight culture were harvested, washed in holding buffer (HB; $25 \mathrm{mM}$ potassium phosphate, $10 \mathrm{mM} \mathrm{MgSO}$, $\mathrm{pH} 7 \cdot 0$ ) and suspended in $250 \mu$ lof a solution containing $50 \mathrm{mM}$ Tris $/ \mathrm{HCl}, 50 \mathrm{mM}$ disodium EDTA, $25 \%$ $(\mathrm{w} / \mathrm{v}$ ) sucrose, $\mathrm{pH} 8 \cdot 0$. Protoplasts were formed by adding $50 \mu \mathrm{l}$ of the same solution containing $100 \mathrm{mg}$ lysozyme $\mathrm{ml}^{-1}$ (freshly prepared) and incubating at $37^{\circ} \mathrm{C}$ for $60-90 \mathrm{~min}$. Protoplasts in the resulting suspension were lysed with $250 \mu \mathrm{l}$ of a solution containing $10 \mathrm{mM}$ Tris $/ \mathrm{HCl}, 5 \mathrm{mM}$ disodium EDTA, $1 \%(\mathrm{w} / \mathrm{v})$ SDS pH 8.0. The above steps were carried out anaerobically to avoid the premature lysis and DNA degradation that ensues when $C$. acetobutylicum encounters oxygen. Thereafter, samples were removed from the anaerobic cabinet and deproteinized by extraction twice with an equal volume of phenol/chloroform pre-equilibrated with TE buffer $(10 \mathrm{mM}$ Tris/HCl, $1 \mathrm{mM}$ disodium EDTA, pH 8.0). Residual phenol was removed by extraction with an equal volume of chloroform/isoamyl alcohol 
$(24: 1, \mathrm{v} / \mathrm{v})$ and nucieic acids were precipitated using $1 \cdot 2 \mathrm{vols}$ propan-2-ol. The fibrous pellet of nucleic acids was rinsed with $70 \%(\mathrm{v} / \mathrm{v})$ ethanol, vacuum-dried and dissolved by incubation for $15 \mathrm{~min}$ at $65^{\circ} \mathrm{C}$ in $50 \mu \mathrm{l}$ TE buffer.

The methods used for extraction of chromosomal DNA for pulsed-field gel electrophoresis were as described previously (Wilkinson \& Young, 1993); electrophoresis conditions werc as indicated in the Figure legend.

Construction of integrational plasmids. Integrational plasmids (see Table 1) were constructed by cloning fragments of $C$. acetobutylicum NCIMB 8052 DNA in the polylinker of plasmid pMTI.30 (Williams et al., 1990). This vector contains the oriT segment of the IncP plasmid RK2 and is efficiently mobilized by IncP plasmids from $E$. coli donors to $C$. acetobutylicum. Integrational plasmids were initially established in $E$. coli strain DH5 $\alpha$ (Hanahan, 1983). They were then transformed into F. coli strain CA474 using the method of Mandel \& Higa (1970), except that the heat-shock step was performed at $30^{\circ} \mathrm{C}$, to avoid induction of the $\lambda$ prophage present in this strain.

Restriction endonucleases and T4 DNA ligase were used in accordance with the suppliers' instructions.

Filter mating procedure. The conjugative mobilization of integrational plasmids from $E$. coli CA474 derivatives to $C$. acetobutylicum NCIMB 8052 was carried out as previously described (Williams et al., 1990), except that mating bacteria were incubated at $30^{\circ} \mathrm{C}$ overnight to avoid induction of the $\lambda$ prophage present in the donor strains. Transconjugants were selected anaerobically at $37^{\circ} \mathrm{C}$ on $\mathrm{CBM}$ containing $10 \mu \mathrm{g}$ crythromycin $\mathrm{ml}^{-1}$. The donor: recipient ratio was approximately 100:1.

Southern blotting and hybridization. DNA fragments in agarose gels were depurinated (Wahl et al., 1979) and transferred to nylon membranes (Hybond-N; Amersham) by capillary blotting (Southern, 1975; Maniatis et al., 1982). Hybridization probes were prepared using a digoxigenin-based non-tadioactive DNA labelling kit (Bochringer) and hybridizations were carried out as indicated by the manufacturer.

Measurement of recombination frequencies. Loss of integrational plasmids from the $C$. acetobutylicum chromosome was monitored, starting with overnight cultures grown in CBM containing $10 \mu \mathrm{g}$ erythromycin $\mathrm{ml}^{-1}$. The bacteria were diluted between $10^{3}$-and $10^{5}$-fold in pre-warmed CBM lacking erythromycin, to permit multiplication of recombinants lacking the integrated plasmid. Growth was monitored until the cell density reached a value corresponding to an $\mathrm{OD}_{600} \sim 1 \cdot 0$. The culture was diluted again and growth monitored as previously. Subculturing steps were repeated until bacterial populations had undergone 20-30 generations of growth. At the beginning and end of each experiment, and at each subculturing step, samples were removed and the viable count was determined by plating serially diluted (in $\mathrm{HB}$ ) samples on non-selective medium (CBM). The colonies that appeared after anaerobic growth for $24 \mathrm{~h}$ were replica-plated on selective medium (CBM with $1 \%$, $\mathrm{w} / \mathrm{v}$, sorbitol instead of glucose for strains harbouring $\mathrm{pJ}$; $\mathrm{CBM}+10 \mu \mathrm{g}$ erythromycin $\mathrm{ml}^{-1}$ for all other strains). The rate of plasmid loss per generation was approximated by dividing the proportion of antibiotic-sensitive (or sorbitol-utilizing) colonies by the number of generations of bacterial growth (Noirot et al., 1987).

Assessment of spore formation. Spore formation was monitored by phase contrast microscopy of bacteria from colonies grown on CBM for $9 \mathrm{~d}$.

\section{RESULTS}

\section{Establishment of integrational plasmids in C. acetobutylicum}

Filter matings were undertaken using L. coli CA474 derivatives harbouring integrational plasmids (see Table 1) as donors and C. acetobutylicum NCIMB 8052 as recipient. The results of a typical experiment are summarized in Table 2. In each experiment, E. coli CA474 donors harbouring pCTC1, a replication-proficient plasmid, and pMTL30, the vector used for constructing integrational plasmids, were employed as controls. The transfer frequencies observed with the pCTC1-containing donor strain were usually between $10^{-4}$ and $10^{-5}$ per recipient, whereas no transconjugants were detected with the pMTL30-containing donor. Donors harbouring integrational plasmids produced transconjugants at frequencies of between $10^{-6}$ and $10^{-7}$ per recipient. For donors harbouring integrational plasmids, the frequency of transconjugants was not strongly dependent on size of the chromosomal insert, over the range employed here.

\section{Integrational plasmids undergo homologous recombination with the bacterial chromosome}

Several lines of evidence indicate that the establishment of integrational plasmids in transconjugants results from homologous recombination between the chromosomal insert and the corresponding region of the bacterial chromosome. Southern hybridization experiments were undertaken with several transconjugants, using the chromosomal inserts from the relevant integrational plasmids as probes. In most cases, though not all (see below), the sizes of the fragments detected after cleavage with three different restriction endonucleases were as expected for integration of a single plasmid copy by a Campbeil-like mechanism. The enzymes chosen had single sites in the pMTL30 vector backbone and no sites in the chromosomal insert. Accordingly, the single hybridizing band present in the parental strain was replaced in the transconjugants by two junction fragments, whose combined size corresponded to the sum of the sizes of the

Table 2. Frequencies of plasmid establishment in C. acetobutylicum after conjugative mobilization from E. coli

\begin{tabular}{|c|c|c|c|}
\hline Plasmid & $\begin{array}{c}\text { Insert } \\
\text { size } \\
(\mathrm{kbp})^{*}\end{array}$ & Replication & $\begin{array}{l}\text { Frequency } \\
\text { per recipicnt }\end{array}$ \\
\hline рСТC1 & - & $\operatorname{Rep}^{+}$ & $1.2 \times 10^{-4}$ \\
\hline pJ1 & $0 \cdot 34$ & Rep $^{-}$ & $4.5 \times 10^{-7}$ \\
\hline PSRW 35 & 0.8 & Rep- & $2.6 \times 10^{-7}$ \\
\hline pSRW38 & 3.8 & $\operatorname{Rep}^{-}$ & $1.7 \times 10^{-6}$ \\
\hline PSRW44 & 0.54 & $\operatorname{Rep}^{-}$ & \\
\hline PMTL30 & & $\operatorname{Rep}^{-}$ & $<4.8 \times 10^{.9}$ \\
\hline
\end{tabular}

*-indicates that the plasmid lacks an insert of chromosomal DN $A$. $\uparrow$ Ability to replicate in $C$. acetobutylicum. 

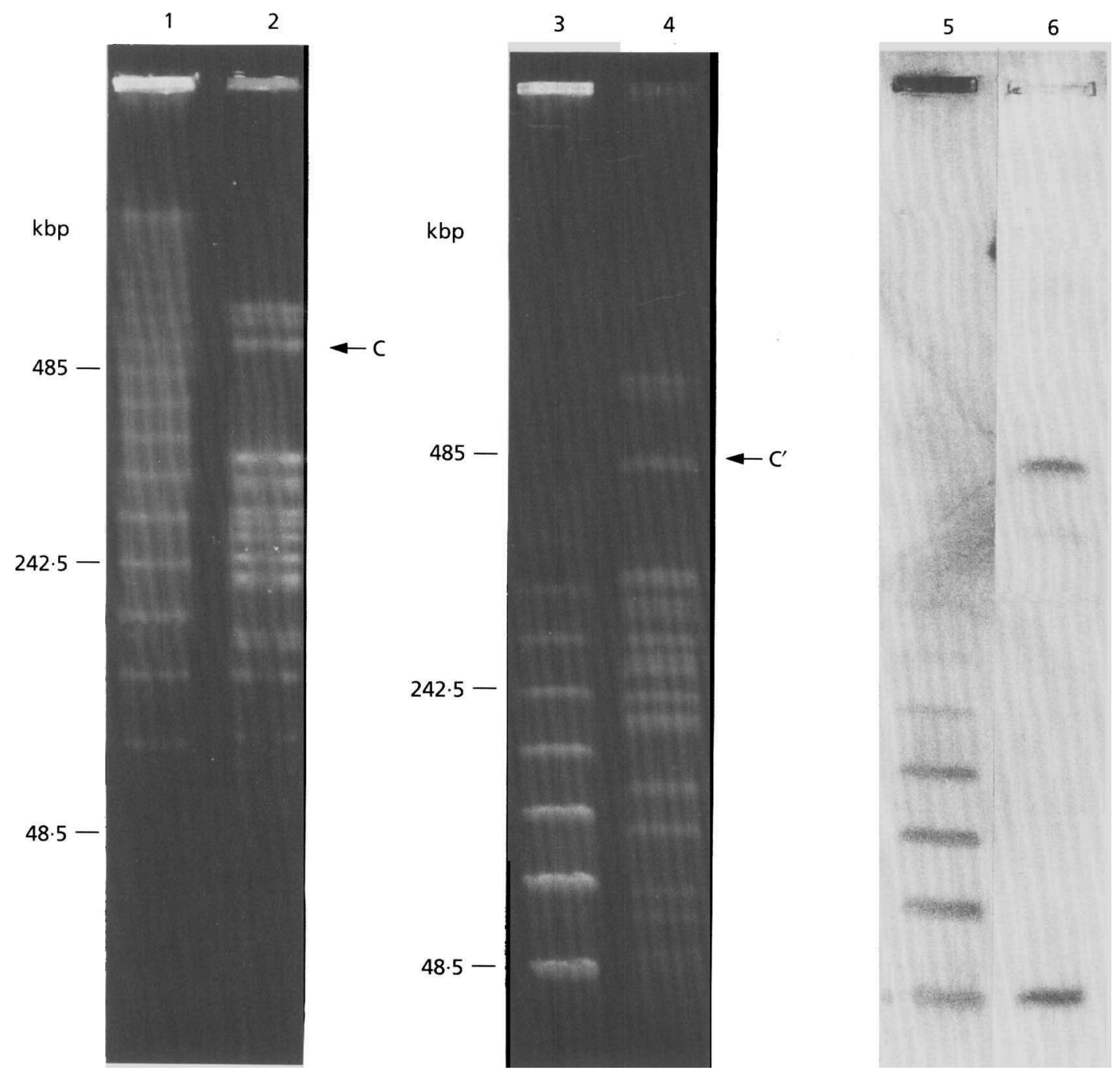

Fig. 1. Insertion of plasmid pSRW 35 into the bacterial chromosome. Lanes 1,3 and $5, \lambda$ concatemers; lane 2, NCIMB 8052 Smal; lanes 4 and 6, AA210 Smal. Electrophoretograms are shown in lanes 1-4, Southern hybridization results in lanes 5 and 6 , using a mixed probe of pSRW35 and $\lambda$ DNA. Fragment SmC, which is visibly altered after integration of pSRW35 (to generate fragment $\mathrm{C}^{\prime}$ ) is indicated in lanes 2 and 4 . Samples in lanes 1 and 2 were subjected to electrophoresis (200 V for $24 \mathrm{~h}$ ) through $1 \%(\mathrm{w} / \mathrm{v})$ agarose in $0.5 \times \mathrm{TBE}$ (Maniatis et al., 1982) maintained at $14{ }^{\circ} \mathrm{C}$ with a linear ramp from $1-60 \mathrm{~s}$. Samples in lanes 3-6 were treated similarly except that electrophoresis was for $20 \mathrm{~h}$ and TAE buffer (Maniatis et al., 1982) was employed.

integrated plasmid and the band present in the parental strain (Young \& Hranueli, 1988).

DNA isolated from two transconjugants harbouring plasmid pSRW35 was digested with SmaI and the resulting macro-restriction fragments separated using pulsed-field gel electrophoresis. In both transconjugants plasmid pSRW35 had apparently inserted at the same site, located about $50 \mathrm{kbp}$ from one end of $\mathrm{SmC}$ (see Wilkinson \& Young, 1993). Since plasmid pSRW35 contains a SmaI site, the SmC fragment found in wild-type DNA was replaced by two $S$ maI fragments in transconjugant DNA (data for one transconjugant are shown in Fig. 1).

Two of the plasmids contain internal fragments of known genes. Plasmid pJ1 contains a $336 \mathrm{bp}$ insert from within gutD (sorbitol dehydrogenase structural gene) and trans- conjugants containing pJ1 were unable to grow using sorbitol as sole source of carbon. Plasmid pSRW44 contains a $540 \mathrm{bp}$ insert from within spo0 $A$ and the single transconjugant obtained containing pSRW44 was unable to form endospores. A more detailed characterization of the phenotype of this Spo0A strain of $C$. acetobutylicum will be published elsewhere. As expected, Campbell-type integration of these plasmids by homologous recombination insertionally inactivated these genes.

\section{Amplification of integrated plasmids}

The results obtained with strain AA243 harbouring plasmid pSR W44 were not as expected for the integration of a single plasmid copy (see above). In experiments employing two different restriction endonucleases $(B g / I I$ 
Table 3. Amplification of an integrational plasmid in the bacterial chromosome

\begin{tabular}{|lll|}
\hline Strain & \multicolumn{1}{c|}{$\begin{array}{c}\text { Size(s) of } \\
\text { hybridizing } \\
\text { fragments* }\end{array}$} \\
\cline { 2 - 3 } & BglII & HindIII \\
\hline NCIMB 8052 & 4.9 & 8.7 \\
AA243 & $6.7 \dagger$ & $7 \cdot 3 \dagger$ \\
& $5.1 \ddagger$ & $6.5 \dagger$ \\
& $3.5 \dagger$ & $5.2 \ddagger$ \\
\hline
\end{tabular}

*'The 540 bp Eco RI-BamHI insert of C. acetobutylicum DNA was used as probe.

† Junction fragments.

‡ Amplified fragment corresponding to linearized pSRW44.

Table 4. Segregation of recombinants lacking integrated plasmids

\begin{tabular}{|llll|}
\hline Strain & $\begin{array}{c}\text { Integrated } \\
\text { plasmid }\end{array}$ & $\begin{array}{c}\text { Insert } \\
\text { size } \\
\text { (kbp) }\end{array}$ & $\begin{array}{c}\text { Recombination } \\
\text { frequency* }\end{array}$ \\
\hline AA210 & pSRW35 & 0.8 & $1.3( \pm 0 \cdot 5) \times 10^{-3}$ \\
AA219 & pJ1 & 0.336 & $3.7( \pm 1 \cdot 9) \times 10^{-4}$ \\
AA225 & pSRW38 & 3.8 & $5 \cdot 6( \pm 1 \cdot 7) \times 10^{-4}$ \\
\hline
\end{tabular}

*Values are means $( \pm \mathrm{SD})$ of three independent determinations.

and HindIII) with unique sites in the pMTL30 vector, two junction fragments would be expected if a single copy of the plasmid was integrated. However, in strain AA243 the expected junction fragments were accompanied by an additional intensely hybridizing band that co-migrated with the linearized integrational plasmid (Table 3). These data indicated that several tandemly repeated plasmid copies had become established by homologous recombination, a phenomenon that has been noted previously with integrational plasmids in Gram-positive bacteria (Young, 1984; Sargent \& Bennett, 1985; Jannière et al., 1985). The number of integrated copies of the amplified plasmid was estimated to be about five, based on the relative intensities of the amplified fragment and the junction fragments (note that the probe used in this experiment was the $540 \mathrm{bp}$ internal fragment of $s p o 0 A$ ).

\section{Stability of strains harbouring integrated plasmids}

Three strains of $C$. acetobutylicum harbouring different integrational plasmids were grown for 20-30 generations in the absence of selective pressure (i.e. erythromycin) and the frequency of segregation of erythromycin-sensitive recombinants was determined as indicated in Methods. The values obtained, which varied from $3.7 \times 10^{-4}$ to $1.3 \times 10^{-3}$ per generation, are summarized in Table 4 . It appeared that segregation frequency was not directly related to size of insert over the range employed here (0.34-3.8 kbp).

\section{DISCUSSION}

This paper establishes the occurrence of genetic exchange involving homologous recombination with the chromosome of the NCIMB 8052 strain of $C$. acetobutylicum. The frequency of integration of three replication-defective plasmids was two to three orders of magnitude less than that of the replication-proficient control (Table 2), suggesting that up to $1 \%$ of the incoming plasmid molecules integrated by homologous recombination. This is only a very rough estimate, since it is based on a comparison of the frequencies of transfer and establishment of different plasmids from different donors, but it does fall within the upper range of frequencies observed for integration of a plasmid showing thermosensitive replication in Lactococcus lactis at the non-permissive temperature (Maguin et al., 1992; Biswas et al., 1993). The frequency of conjugative mobilization from E. coli was sufficiently high to permit recovery of transconjugants containing nonreplicative plasmids inserted into the bacterial chromosome. The reported frequencies of plasmid establishment following protoplast transformation of the NI-4081 strain $\left(10^{6}\right.$ per $\mu \mathrm{g}$ DNA; Azeddoug et al., 1992) and electrotransformation of the NCIMB 8052 strain $\left(10^{3}\right.$ per $\mu \mathrm{g}$ DNA; Oultram et al., 1988) suggest that these methods could also be employed for introducing integrational plasmids into these two very similar strains (Wilkinson \& Young, 1993). Other commonly used laboratory strains of C. acetobutylicum (ATCC 824, DSM 1731 and NCP 262) are not, apparently, so closely related to the NCIMB 8052 strain (Wilkinson \& Young, 1993) and it remains to be seen whether integrational plasmid technology will also be as readily applicable to these organisms.

In Bacillus subtilis and L. lactis the frequency of homologous recombination between DNA molecules is quite strongly dependent on length of the homologous DNA segment (Michel et al., 1983; Michel \& Ehrlich, 1984; Khasanov et al., 1992; Biswas et al., 1993). In the experiments reported here (Table 2 ) the plasmid bearing a $3.8 \mathrm{kbp}$ segment of the bacterial chromosome became established at a frequency that was only four- to sevenfold higher than that observed for the two plasmids with shorter homologous DNA segments (336 bp and about $800 \mathrm{bp}$ ). Recombination frequency is affected by many factors in addition to length of the region of homology. These include chromosomal location, DNA base composition and sequence (Cox \& Lehman, 1987; Vagner \& Ehrlich, 1988; Gruss et al., 1991; Biswas et al., 1992). A carefully controlled study will be required before any firm conclusions can be drawn concerning the dependence of recombination frequency on extent of homology in $C$. acetobutylicum.

Integrational plasmids generate a duplication of host DNA sequences upon insertion. Excision (reversal of the integration event) generally occurs at a low frequency (less than $10^{-4}$ per generation) in B. subtilis and L. lactis 
(Vagner \& Ehrlich, 1988; Young \& Ehrlich, 1989; Leenhouts et al., 1989). The values obtained here are about an order of magnitude higher than those observed in B. subtilis and L. lactis. This may indicate the existence of a particularly active system of homologous recombination in the NCIMB 8052 strain of C. acetobutylicum. However, the explanation may be of a trivial nature. For example, recombinants lacking the integrated plasmids may have a more rapid growth rate than parental strains. Alternatively, the observed differences may simply reflect variations in the methods used to assess recombination frequency in the different organisms. For the experiments with B. subtilis, fluctuation tests (Vagner \& Ehrlich, 1988) or establishment of bacterial cultures from single cell inocula (Young \& Ehrlich, 1989) were employed. For the experiments with $C$. acetobutylicum, cultures were established with an initial inoculum density of between $5 \times 10^{2}$ and $5 \times 10^{4}$ c.f.u. $\mathrm{ml}^{-1}$ because lower density inocula did not grow reproducibly. Further experiments will be required to distinguish between these possibilities.

Integrational plasmids have played a cardinal role in genetic analysis in $B$. subtilis. They have been employed for: (i) determining the map location and extent of cloned genes; (ii) undertaking insertional mutagenesis, mutational cloning and gene replacement; (iii) constructing gene fusions and merodiploid strains; (iv) controlled stable amplification of genes; (v) cloning replication origins (reviewed by Dowds et al., 1988; Young \& Hranueli, 1988; Perego, 1993). Integrational plasmids are also being used extensively in several other Gram-positive bacteria, including streptomycetes and lactic acid bacteria (Kieser \& Hopwood, 1991; Chassy \& Murphy, 1993). This paper establishes that they can be employed in $C$. acetobutylicum for at least three of the applications mentioned above (viz. determination of map location, insertional mutagenesis and gene amplification). It seems likely that integrational plasmids will prove to be powerful and versatile tools for genetic analysis in $C$. acetobutylicum.

\section{ACKNOWLEDGEMENTS}

We thank M. Mauchline, N. P. Minton and J. D. Oultram, PHLS, Porton Down, UK, and D. Brown and P. Youngman, University of Georgia, Athens, USA, for providing plasmids pBTM100, pJ1 and pCACB4. The financial support of the SERC Biotechnology Directorate is gratefully acknowledged.

\section{REFERENCES}

Azeddoug, H., Hubert, J. \& Reysset, G. (1992). Stable inheritance of shuttle vectors based on plasmid pIM13 in a mutant strain of Clostridium acetobutylicum. J Gen Microbiol 138, 1371-1378.

Bertram, J., Kuhn, A. \& Düre, P. (1990). Tn916-induced mutants of Clostridium acetobutylicum defective in regulation of solvent formation. Arch Microbiol 153, 373-377.

Biswas, I., Vagner, V. \& Ehrlich, S. D. (1992). Efficiency of homologous intermolecular recombination at different locations on the Bacillus subtilis chromosome. J Bacteriol 174, 5593-5596.

Biswas, I., Gruss, A., Ehrlich, S. D. \& Maguin, E. (1993). Highefficiency gene inactivation and replacement system for Grampositive bacteria. J Bacteriol 175, 3628-3635.
Boyer, H. W. \& Roulland-Dussoix, D. (1969). A complementation analysis of the restriction and modification of DNA in Escherichia coli. J Mol Biol 41, 459-472.

Campbell, A. M. (1962). Episomes. Adv Genet 11, 101-146.

Chassy, B. M. \& Murphy, C. M. (1993). Lactococcus and Lactobacillus. In Bacillus subtilis and other Gram-positive Bacteria: Biochemistry, Physiology and Molecular Genetics, pp. 65-82. Edited by A. L. Sonenshein, J. A. Hoch \& R. Losick. Washington, DC: American Society for Microbiology.

Cox, M. M. \& Lehman, I. R. (1987). Enzymes of general recombination. Annu Rev Biocbem 56, 229-262.

Del Sal, G., Manfioletti, G. \& Schneider, C. (1988). A one tube plasmid DNA mini-preparation suitable for sequencing. Nucleic Acids Res 16, 9878.

Dowds, B. C. A., O'Kane, C., Gormley, E., McConnell, D. J. \& Devine, K. M. (1988). Integrating plasmids in the genetic engineering of bacilli. In Recombinant DN $A$ and Bacterial Fermentation, pp. 137-156. Edited by J. A. Thomson. Boca Raton, Florida: CRC Press.

Gruss, A., Moretto, V., Ehrlich, S. D., Duwat, P. \& Dabert, P. (1991). GC-rich DNA sequences block homologous recombination in vitro. $J$ Biol Chem 266, 6667-6669.

Hanahan, D. (1983). Studies on transformation of Escherichia coli with plasmids. J Mol Biol 166, 557-579.

Hedges, R. W. \& Jacob, A. E. (1974). Transposition of ampicillin resistance from RP4 to other replicons. Mol \& Gen Genet 132, 31-34.

Jannière, L., Niaudet, B., Pierre, E. \& Ehrlich, S. D. (1985). Stable gene amplification in the chromosome of Bacillus subtilis. Gene $\mathbf{4 0}$, $47-55$.

Jones, D. T. \& Woods, D. R. (1986). Acetone-butanol fermentation revisited. Microbiol Rev 50, 484-524.

Khasanov, F. K., Zvingila, D. J., Zainullin, A. A. \& Prozorov, A. A. (1992). Homologous recombination between plasmid and chromosomal DNA in Bacillus subtilis requires approximately $70 \mathrm{bp}$ of homology. Mol \& Gen Genet 234, 494-497.

Kieser, T. \& Hopwood, D. A. (1991). Genetic manipulation of Streptomyces: integrating vectors and gene replacement. Methods Envymol 204, 430-458.

Leenhouts, K. J., Kok, J. \& Venema, G. (1989). Campbell-like integration of heterologous plasmid DNA into the chromosome of Lactococcus lactis subsp. lactis. Appl Environ Microbiol 55, 394- 400.

Maguin, E., Duwat, P., Hege, T., Ehrlich, S. D. \& Gruss, A. (1992). New thermosensitive plasmid for Gram-positive bacteria.J Bacteriol 174, 5633-5638.

Mandel, M. \& Higa, A. (1970). Calcium-dependent bacteriophage DNA infection. J Mol Biol 53, 159-162.

Maniatis, T., Fritsch, E. F. \& Sambrook, J. (1982). Molecular Cloning: A Laboratory Manual. Cold Spring Harbor, NY: Cold Spring Harbor Laboratory.

Mermelstein, L. D., Welker, N. E., Bennett, G. N. \& Papoutsakis, E. T. (1992). Expression of cloned homologous fermentative genes in Clostridium acetobutylicum ATCC 824. Biotecbnol 10, 190-195.

Michel, B., Niaudet, B. \& Ehrlich, S. D. (1983). Intermolecular recombination during transformation of Bacillus subtilis competent cells by monomeric and dimeric plasmids. Plasmid 10, 1-10.

Michel, B. \& Ehrlich, S. D. (1984). Recombination efficiency is a quadratic function of the length of homology during plasmid transformation of Bacillus subtilis protoplasts and Escherichia coli competent cells. EMBO J 3, 2879-2884.

Minton, N. P., Swinfield, T.-J, Brehm, J. K., Whelan, S. M. \& Oultram, J. D. (1993). Vectors for use in Clostridium acetobutylicum. 
In Genetics and Molecular Biology of Anaerobic Bacteria, pp. 120-140. Edited by M. Sebald. New York: Springer.

Noirot, Ph., Petit, M.-A. \& Ehrlich, S. D. (1987). Plasmid replication stimulates DNA recombination in Bacillus subtilis. J Mol Biol 196, 39-48.

Norrander, J., Kempe, T. \& Messing, J. (1983). Construction of improved M13 vectors using oligodeoxynucleotide-directed mutagenesis. Gene 27, 101-106.

O'Brien, R. W. \& Morris, J. G. (1971). Oxygen and the growth and metabolism of Clostridium acetobutylicum. J Gen Microbiol 68, 307-318.

Oultram, J.D., Loughlin, M., Swinfield, T.-J., Brehm, J. K., Thompson, D. E. \& Minton, N. P. (1988). Introduction of plasmids into whole cells of Clostridium acetobutylicum by electroporation. FEMS Microbiol Lett 56, 83-88.

Perego, M. (1993). Integrational vectors for genetic manipulation in Bacillus subtilis. In Bacillus subtilis and other Gram-positive Bacteria: Biochemistry, Physiology and Molecular Genetics, pp. 615-624. Edited by A. L. Sonenshein, J. A. Hoch \& R. Losick. Washington, DC: American Society for Microbiology.

Piggot, P. J. \& Curtis, C. A. M. (1987). Analysis of the regulation of gene expression during Bacillus subtilis sporulation by manipulation of the copy number of spo-lac $Z$ fusions. J Bacteriol 169, 1260-1266.

Piggot, P. J., Curtis, C. A. M. \& de Lencastre, H. (1984). Use of integrational plasmid vectors to demonstrate the polycistronic nature of a transcriptional unit $(s p o I I A)$ required for sporulation of Bacillus subtilis. J Gen Microbiol 130, 2123-2136.

Sargent, M. G. \& Bennett, M. F. (1985). Amplification of a major membrane-bound DNA sequence of Bacillus subtilis. J Bacteriol 161, 589-595.

Southern, E. (1975). Detection of specific sequences among DNA fragments separated by gel electrophoresis. J Mol Biol 98, 503-517.

Stojanović, S., Hranueli, D. \& Young, M. (1992). Evidence that recombination between reiterated sequences in the Bacillus subtilis chromosome does not occur via unequal crossing over. Biochimie 74, 713-721.
Twigg, A. J. \& Sherratt, D. (1980). Trans-complementable mutants of plasmid ColE1. Nature 283, 216-218.

Vagner, V. \& Ehrlich, S. D. (1988). The efficiency of homologous recombination varies along the Bacillus subtilis chromosome. J Bacteriol 170, 3978-3982.

Wahl, G. M., Stern, M. \& Stark, G. R. (1979). Efficient transfer of large DNA fragments from agarose gels to diazobenzyloxymethylpaper and rapid hybridization by using dextran sulfate. Proc Natl Acad Sci US A 76, 3683-3687.

Wilkinson, S. R. \& Young, M. (1993). Wide diversity of genome size among different strains of Clostridium acetobutylicum. J Gen Microbiol 139, 1069-1076.

Williams, D. R., Young, D. I. \& Young, M. (1990). Conjugative plasmid transfer from Escherichia coli to Clostridium acetobutylicum. $J$ Gen Microbiol 136, 819-826.

Woolley, R. C., Pennock, A., Ashton, R. J., Davies, A. \& Young, M. (1989). Transfer of $\operatorname{Tn} 1545$ and $\operatorname{Tn} 916$ to Clostridium acetobutylicum. Plasmid 22, 169-174.

Young, M. (1984). Gene amplification in Bacillus subtilis. J Gen Microbiol 130, 1613-1621.

Young, M. \& Cole, S. T. (1993). Clostridium. In Bacillus subtilis and other Gram-positive Bacteria: Biochemistry, Physiology and Molecular Genetics, pp. 35-52. Edited by A. L. Sonenshein, J. A. Hoch \& R. Losick. Washington, DC: American Society for Microbiology.

Young, M. \& Ehrlich, S. D. (1989). Stability of reiterated sequences in the Bacillus subtilis chromosome. J Bacteriol 171, 2653-2656.

Young, M. \& Hranueli, D. (1988). Chromosomal gene amplification in Gram-positive bacteria. In Recombinant DNA and Bacterial Fermentation, pp. 157-200. Edited by J. Thomson. Boca Raton, Florida: CRC Press.

Young, M., Staudenbauer, W. L. \& Minton, N. P. (1989). Recent advances in the genetics of the clostridia. FEMS Microbiol Rev 63, 301-325.

Received 11 June 1993; revised 6 August 1993; accepted 17 August 1993. 